\title{
Pengaruh Situs Pembelajaran Online Terhadap Proses Pembelajaran Siswa Di Madrasah Aliyah Al-Bairuny Jombang
}

\author{
Fatoni Achmad, ${ }^{1}$ Risna Srinawati, ${ }^{2}$ Alivia Septa Pamungkas, ${ }^{3}$ \\ FKIP Unkhair Ternate, FKIP Unkhair Ternate, FMIPA Unsoed \\ Email: lord.fatoniachmad@gmail.com
}

\begin{abstract}
Abstrak Penelitian ini bertujuan untuk mengetahui pengaruh situs pembelajaran online terhadap proses pembelajaran siswa di Madrasah Aliyah Al-Bairuny Jombang.Metode yang digunakan dalam penelitian adalah kualitatif. Jenis penelitian field research, sedangkan teknik pengumpulan datanya dengan menggunakan wawancara dan dokumentasi. Hasil penelitian menunjukkan bahwa situs pembelajaran online berpengaruh terhadap proses pembelajaran siswa di Madrasah Aliyah Al-Bairuny Jombang. Dari tiga puluh jawaban yang diterima sebanyak $74 \%$ siswa menggunakan situs pembelajaraan online, $16 \%$ terkadang menggunakan dan $10 \%$ tidak menggunakan situs pembelajaran online.
\end{abstract}

Kata Kunci : Situs, Pembelajaran, Online, Siswa

\begin{abstract}
This study aims to determine the effect of online learning sites on the learning process of students at Madrasah Aliyah Al-Bairuny Jombang. The method used in this research is qualitative. This type of research is field research, while the data collection techniques use interviews and documentation. The results showed that online learning sites had an effect on the student learning process at Madrasah Aliyah Al-Bairuny Jombang. Of the thirty answers received, $74 \%$ of students used online learning sites, $16 \%$ sometimes used and $10 \%$ did not use online learning sites.
\end{abstract}

Keywords: Site, Learning, Online, Students 


\section{PENDAHULUAN}

Pada abad ke dua puluh satu ini dunia berkembang begitu cepat. Perkembangan tersebut telah mencakup hampir seluruh aspek dalam kehidupan manusia. Salah satu aspek yang dipengaruhi adalah dalam dalam bidang pendidikan dan ilmu pengetahuan. Pada zaman yang serba canggih seperti sekarang ini informasi semakin mudah didapatkan. Melalui internet siapapun mampu menggali informasi mengenai suatu hal kapanpun dan dimanapun. Hal ini juga berpengaruh terhadap pola pengajaran diera sekarang ini.

Metode yang digunakan guru sudah semakin beragam yang tentunya menyesuaikan dengan perkembangan zaman. Sekarang ini sudah banyak situssitus diinternet yang menyediakan layanan informasi belajar. Melalui layanan pembelajaran tersebut siswa diharapkan mendapat informasi yang lebih serta melatih kemandirian siswa dalam belajar tanpa didampingi oleh guru. Selain itu situs pembelajaran juga menyediakan layanan belajar melalui penjelasan yang dikemas dalam bentuk video dengan tujuan agar pelajar lebih paham karena seolah-olah mereka sedang diajar oleh guru atau tutor.

Namun walaupun demikian situs pembelajaran tidak selalu membawa hal yang positif tetapi juga bisa berdampak negative pada siswa-siswi. Dalam suatusitus tidak jarang terdapat hal-hal yang tidak seharusnya dilihat oleh kalangan pelajar. Banyak pihak yang memanfaatkan situs pembelajaran untuk kepentingan pribadi misal mempromosikan produk-produk orang dewasa yang seharusnya tidak untuk kalangan pelajar. Selain itu secara otomatis sifat individualistic akan muncul ketika anak mengakses situs pembelajaran karena ia akan merasa bisa tanpa bantuan orang lain dengan kata lain hal tersebut mampu mengurangi interaksi siswa dengan siswa yang lain.

Berdasarkan uraian diatas penulis memilih judul "Pengaruh Situs Pembelajaran Online terhadap proses pembelajaran Siswa di MA Al-Bairuny Jombang". Hal tersebut bertujuan untuk memaparkan bagaimana pengaruh situs pembelajaran online bagi proses belajar jika ditinjau dari prespektif siswa-siswi 
dan juga guru serta bagaimana pancasila menanggapi fenomena yang terjadi dalam bidang pendidikan.

\section{LANDASAN TEORI}

Menurut Kamus Besar Bahasa Indonesia (KBBI) belajar adalah berusaha memperoleh kepandaian atau ilmu. Dengan kata lain belajar merupakan proses usaha yang dilakukan oleh makhluk hidup dari kondisi tidak tahu menjadi tahu. Sedangkan pembelajaran merupakan suatu proses, cara atau perbuatan menjadikan makhluk hidup belajar. Atau jika diuraikan pembelajaran adalah proses yang menjadikan makhluk tersebut belajar. Belajar pada hakikatnya merupakan proses menuju kedewasaan seorang manusia ${ }^{1}$. Sehingga belajar dianggap sebagai kebutuhan dasar manusia serta merupakan ciri khas dari manusia. Tujuan dari keduanya adalah agar manusia atau makhluk hidup lainnya mengenal hal-hal baru. Dengan mengenal hal-hal baru tersebut akan memancing otak manusia untuk bekreasi sehingga menghasilkan suatu karya dan juga prestasi.

Seperti pendapat yang dikemukakan oleh Syaiful Bahri Djamarah bahwa prestasi merupakan hasil dari suatu kegiatan yang telah dilakukan atau dikerjakan, diciptakan yang menyenangkan hati dan diperoleh dengan sifat keuletan dalam bekerja baik secara individu maupun bekelompok dan dalam bidang tertentu ${ }^{2}$. Dari definisi tersebut dapat ditarik kesimpulan bahwa dibutuhkan kerja keras serta keuletan yang tinggi untuk menggapai suatu prestasi. Secara umum prestasi dipengeruhi oleh beberapa factor, yakni factor internal dan factor eksternal.

Factor internal merupakan factor yang berasal dari dalam diri individu dan dapat mempengaruhi hasil belajar suatu individu. Hal tersebut menunjukkan bahwa terdapat factor dari dalam diri yang mampu meningkatkan prestasi suatu individu. Namun hal tersebut terkadaang tidak disadari oleh individu tersebut.

\footnotetext{
${ }^{1}$ Arinda Firdianti, Implementasi Manajemen Berbasis Sekolah Dalam Meningkatkan Prestasi Belajar Siswa, Yogyakarta:CV GRE PUBLISHING,2018.hal.51.

${ }^{2}$ Syaiful Bahri Djamarah, Prestasi Belajar dan Kompetensi Guru,Surabaya:Usaha Nasional,1994.hal.21.
} 
Faktor internal terdiri atas (1)factor fisiologis(yaitu : factor kesehatan dan factor cacat), (2) factor psikoligis yang meliputi intelegensi, perhatian, dan pemenuhan sarana pembelajaran. Sedangkan factor eksternal adalah factor yang berasal dari luar yang mampu mendukung sesorang untuk mencapai prestasi. ${ }^{3}$

Dalam proses belajar metode yang digunakan beraneka ragam. Secara umum metode pengajaran dibagi menjadi dua yakni pengajaran dengan bahan ajar cetak dan bahan ajar elektronik. Pada bahan cetak materi pembelajaran disampaikan melalui modul atau buku cetak yang dibuat oleh pendidik untuk diberikan kepada peserta didik. Pada metode elektronik bahan ajar merupakan materi pembelajaran yang dibuat dengan bantuan teknologi sehingga memiliki sajian yang berbeda. Materi dapat disajikan dalam bentuk web atau bisa disebut dengan istilah e-learning. ${ }^{4}$

Keunggulan dari e-learning adalah memungkinkan peserta didik untuk mengakses dengan waktu dan tempat sesuai yang ia kehendaki. Hal tersebut akan menciptakan suasana yang lebih nyaman bagi peserta didik. Selain itu dengan metode e-learning ini mampu mebuat siswa untuk lebih aktif dan mandiri dalam belajar. Keunggulan lainnya adalah informasi dapat diperbarui kapanpun sehingga meminimalisir kesalahan informasi. Namun metode ini juga memiliki kekurangan yaitu keberhasilan pembelajaran tergantung pada keaktifan peserta didik. Pada peserta didik yang kurang aktif dan kurang antusias terhadap web maka akan tertinggal informasi yang seharusnya mereka dapatkan. Kelemahan lain adalah pada siswa-siswi yang memiliki keterbatasan dalam fasilitas internet. Internet yang kurang memadai akan membuat peserta didik tidak mampu menyerap informasi secara maksimal.

Sumber pembelajaran online adalah materi yang dikembangkan melalui internet baik berupa website, teks, audio, visual, multimedia, dan video yang disimpan secara digital dalam situs-situs web yang nantinya dapat dibuka atau

\footnotetext{
${ }^{3}$ Arinda Firdianti,Implementasi Manajemen Berbasis Sekolah Dalam Meningkatkan Belajar Siswa,Yogyakarta:CV GRE PUBLISHING,2018.hal 53.

${ }^{4}$ Hamdan Husein Batubara,Pembelajaran Berbasis Web Dengan Moodle Versi 3.4,Yogyakarta:Deepublish,2018.hal.9.
} 
diakses kapan aja dan dimana saja ${ }^{5}$. Dalam beberapa situs tersedia forum yang memfasilitasi diskusi antara pendidik dengan peserta didik dengan bantuan teknologi pembelajaran. Karakteristik pembelajaran online adalah sebagi berikut :

1. Konten e-learning dapat diintegrasikan dengan pembelajaran oleh guru, tugas-tugas individu atau tugas-tugas berkelompok yang menuntuk siswa-siswi untuk berkolaborasi.

2. Perserta didik maupun pengajar atau semua pihak yang terlibat dapat menggunakan alat-alat komunikasi seperti e-mail, chating, polls, whiteboards, forum diskusi, sharing aplikasi, dan video konferensi.

3. Tahap akhir pembelajaran biasanya diberikan latihan-latihan sebagai indicator pengukur kemampuan peserta didik.

4. Bisa dilaksanakan secara synchronous atau asynchronous. ${ }^{6}$

\section{HAIL DAN PEMBAHASAN}

\section{Hakikat Belajar dan Pembelajaran}

Belajar merupakan rangkaian kegiatan atau aktivitas yang dilakukan dalam kondisi sadar oleh manusia dan mengakibatkan perubahan dalam dirinya berupa penambahan ilmu, pengetahuan,dan wawasan berdasarkan pengamatan dan pengalaman. Belajar merupakan kewajiban bagi setiap manusia ${ }^{7}$. Bahkan dalam agama islam menyatakan bahwa belajar itu wajib dari rahim ibu hingga liang lahat. Belajar dapat dikategorikan sebagai kebutuhan manusia. Manusia perlu belajar untuk menjalankan dinamika kehidupan yang terus berubah seiring perkembangan zaman. Sedangkan pembelajaran adalah bantuan yang diberikan oleh pengajar atau orang yang memiliki pengetahuan dibidang tertentu agar terjadi proses penerimaan ilmu dan pengetahuan. Dalam

${ }^{5}$ Muhammad Yaumi,Media Teknologi Pembelajaran,Jakarta:PRENAMEDIA GROUP,2018.hal.208-209.

${ }^{6}$ Muhammad Rusli dkk, Multimedia Pembelajaran yang Inovatif Prinsip Pengembangan Model,Yogyakarta:Penerbit ANDI,2017. hal.81. 
pembelajaran terdapat beberapa teori yang menjelaskan mengenai bagaimana manusia belajar yang hal tersebut dapat digunakan untu memahami proses inhern yang kompleks dalam belajar. Berikut merupakan teori-teori pembelajaran:

\section{A. Teori Deskriptif dan Prespektif}

Teori deskriptif merupakan teori yang menempatkan kondisi dan metode pembelajaran sebagai given dan memberikan hasil pembelajaran sebagai variable yang diamati ${ }^{8}$. Menurut definisi tersebut dapat disimpulkan bahwa teori deskriptif membahas atau mengamati hasil yang nyata, hasil pembelajaran yang muncul bisa jadi hasil yang muncul bukan merupakan hasil pembelajaran yang diinginkan. Dengan demikian dapat dikatakan bahwa pembelajaran deskriptif merupakan teori yang membahas mengenai hasil pembelajaran yang muncul karena digunakannya metode-metode tertentu.

Teori prespektif merupakan teori yang berisi seperangkat preskripsi untuk mengoptimalkan hasil yang diinginkan dibawah kondisi tertentu. Jika deskripsi tersebut dijelaskan maka teori ini menjelaskan mengenai cara untuk mencapai hasil pembelajaran yang diinginkan. Perbedaan teori prespektif dengan deskriptif adalah terletak pada kajiannya. Jika teori deskriptif mengkaji mengenai hasil pembelajaran maka teori prespektif ini membahas mengenai proses mencapai tujuan atau hasil tersebut.

\section{B. Teori Behavioristik}

Teori kedua yang membahas mengenai pembelajaran adalah teori behavioristik. Menurut teori behavioristik belajar adalah perubahan tingkah laku sebagai akibat dari adanya interaksi antara

${ }^{8}$ Darmadi,Pengembangan Model dan Metode Pembelajaran dalam Dinamika Belajar
Siswa,Yogyakarta:CV BUDI UTAMA,2017.hal.3. 
stimulus (rangsangan) dan respon (tanggapan) ${ }^{9}$. Dengan kata lain seseorang dikatakan telah belajar apabila telah terjadi perubahan pada dirinya. Dan perubahan tersebut merupakan interaksi antara rangsangan dan tanggapan seperti yang telah dijelaskan pada deskripsi. Perubahan yang dimaksud merupakan perubahan yang berhubungan dengan tingkah laku, pemikiran, keahlian dan lain-lain.

Teori behavioristik ini merupakan teori yang merajai praktik pendidikan di Indosia. Hal tersebut dibuktikan dengan pendirian lembaga pendidikan seperti Taman Kanak-kanak (TK), Sekolah Dasar (SD) hingga tingkat perguruan tinggi atau sejenisnya yang menerapkan metode pembiasaan untuk para siswa-siswinya. Teori behavioristik memiliki prinsip-prinsip yaitu belajar merupakan perubahan tingkah laku dan orang dikatakaan belajar apabila dirinya mampu menunjukkan adanya perubahan tingkah laku.

\section{Teori Kognitif}

Pembahasan pada teori kognitif merupakan proses pembelajaran bukan hasil dari pembelajaran tersebut. Teori kognitif berpandangan bahwa belajar merupakan aktifitas yang melibatkan proses berfikir yang kompleks yakni meliputi ingatan, pengelolaan informasi,emosi,serta bentuk pengelolaan jiwa yang lain ${ }^{10}$. Jadi belajar merupakan aktivitas kompleks yang mencakup semua konteks. Menurut teori ini tingkah laku seseorang ditentukan dari pemahamannya terhadap tujuan belajar. Jadi belajar tidak hanya dapat diukur dari perubahan tingkah laku seperti halnya yang dijelaskan dalam teori behavioristik. Melainkan tingkah laku ditunjukkan melalui pemahaman tentang situasi yang merupakan tujuan dari pembelajaran yang ia lakukan.

\footnotetext{
${ }^{9}$ Ibid.hal.3.

${ }^{10}$ Darmadi,Pengembangan Model dan Metode Pembelajaran dalam Dinamika Belajar Siswa,Yogyakarta:CV BUDI UTAMA,2017.hal.10.
} 


\section{Teori Konstruktiv}

Teori konstruktiv merupakan teori pembelajaran yang lebih menekankan pada proses dan kebebasan dalam menggali pengetahuan dengan upaya mengkonstruksi pengalaman ${ }^{11}$. Dengan kata lain teori ini memberi kebebasan kepada siswa-siswi untuk mengasah kreativitas dan imajinasi yang mereka miliki untuk berkompetisi, memahami ilmu pengetahuan dan tekonolgi, dan mengembangkan potensi dalam diri mereka sendiri. Dalam proses pembelajarannya siswa diberi kebebasan untuk berimajinasi dengan bahasa mereka sendiri sesuai dengan pengalaman masing -masing sehingga mampu menciptakan lingkungan dengan suasana belajar yang kondusif. Tujuan teori konstrukstiv adalah mengembangkan kreatifitas siswa-siswi serta member motivasi bahwa belajar merupakan tanggung jawab masing-masing serta mengajarkan pada siswa-siswi mengenai kemandirian dalam belajar ${ }^{12}$.

\section{Media Pembelajaran}

Secara bahasa kata media berasal dari bahasa latin " medium " yang artinya adalah perantara. Sedangakan menurut tokoh bernama $\mathrm{H}$. Malik mengemukakan bahwa media belajar adalah segala sesuatu yang dapat digunakan untuk menyalurkan pesan yang berupa bahan pembelajaran sehingga dapat merangsang perhatian, minat, pikiran dan perasaan pembelajar dalam kegiatan belajar untuk mencapai tujuan pembelajaran tertentu ${ }^{13}$. Dengan kata lin media merupakan alat bantu yang digunakan pengajar untuk menyampaikan materi kepada siswa-siswi baik berupa visual maupun audio.

\footnotetext{
${ }^{11}$ Ibid.hal.17-18.

${ }^{12}$ Darmadi,Pengembangan Model dan Metode Pembelajaran dalam Dinamika Belajar Siswa, Yogyakarta:CV BUDI UTAMA,2017.hal.17.

${ }^{13}$ Rudi Sumiharsono,Media Pembelajaran,Jember:CV PUSTAKA ABADI,2017.hal.9.
} 
Fungsi dari media pembelajaran secara umum adalah membantu penyampaian materi agar lebih mudah dipahami oleh peserta didik. Menurut Levie \& Lentnz fungsi media pembelajaran adalah sebagai berikut.

\section{a. Fungsi Atensi}

Fungsi atensi merupakan fungsi media pembelajaran yang berfokus pada mengarahkan perhatian dan konsentrasi siswa-siswi pada isi pelajaran yang disampaikan yang berkaitan makna visual atau menyertai teks materi pelajaran ${ }^{14}$.

\section{b. Fungsi Afektif}

Fungsi afektif berhubungan dengan emosi atau kondisi psikologis siswa-siswi. Gambar visual dapat menggugah emosi dan sikap siswa, misalkan pada informasi yang berhubungan dengan masalah social dan $\operatorname{ras}^{15}$.

\section{c. Fungsi Kognitif}

Fungsi kognitif dapat dilihat dari penemuan yang mengungkapkan bahwa gambar mempermudah mencapai tujuan untuk memahami dan mengingat informasi. Dengan kata lain siswa-siswi akan lebih mengingat informasi yang disertai gambar ${ }^{16}$.

\section{d. Fungsi Kompesatoris}

Fungsi kompesatoris menjelaskan bahwa media pembelajaran berfungsi untuk mengakomodasikan siswa-siswi yang lemah dan lambat menerima informasi yang disajikan dengan teks atau yang disajikan secara verbal ${ }^{17}$.

Dari beberapa penjelasan mengenai fungsi media pembelajaran diatas dapat disimpulakn bahwa media pembelajaran merupakan

\footnotetext{
${ }^{14}$ Ibid. hal.12

${ }^{15}$ Ibid.hal.12.

${ }^{16}$ Ibid.hal.12.

${ }^{17}$ Ibid.hal.13.
} 
komponen penting dalam proses belajar. Media pembelajaran mampu membantu siswa-siswi untuk mengingat informasi yang diberikan serta membantu mereka yang memiliki daya tamping ilmu yang lemah untuk bisa memahami materi. Jadi dapat dikatakan bahwa media pembelajaran merupakan sarana pemerataan pemahaman materi kepada siswa-siswi.

\section{Pembelajaran dengan Media Internet}

\section{a. Pengertian Internet}

Seperti yang kita ketahui bersama bahwa internet telah mencakup seluruh aspek dalam kehidupan manusia termasuk dalam bidang pendidikan. Seiring dengan perkembangan zaman kini internet digunakan sebagi media pembelajaran. Oleh karena itu perlu kita ketahui apa itu internet dan bagaimana peran dalam dunia pembelajaran. Internet adalah kumpulan atau jaringan dari computer yang berada pada seluruh dunia. Internet merupakan kependekan dari interconnection-networking secara harfiah ialah system global dari seluruh jaringan computer yang terhubung satu sama lain dengan menggunakan standar Internet Protocol Suite (TCP/IP) untuk melayani seluruh pengguna didunia yang berjumlah hingga miliaran pengguna. Internet menyediakan akses untuk layanan telekomunikasi dan sumber daya komunikasi untuk jutaan pemakainya yang tersebar diseluruh penjuru dunia. ${ }^{18}$

Dari pemikiran tokoh-tokoh diatas dapat disimpulakan bahwa internet merupakan jaringan komunikasi yang memiliki fungsi member informasi-informasi sesuai yang dibutuhkan oleh pengakses. Selain itu internet dapat dijadikan sebagai media partner dalam hidup manusia baik untuk keperluan pekerjaan, hiburan, dan bahkan pendidikan.

${ }^{18}$ Siti Rohaya,Internet : Pengertian,Sejarah,Fasilitas Dan Koneksinya,Yogyakarta,2008.diakses pada 26 Desember 2018 pukul 11.33 WIB. 
Seperti halnya dengan dunia nyata dunia internet juga memiliki alamat untuk mencari keberadaan informasi-informasi yang diinginkan. Alamat dalam intenet dikenal dengan istilah domain name atau nama domain ${ }^{19}$. Nama domain ini bersifat otentik jadi tidak ada satu namapun yang sama diseluruh dunia. Informasi-informasi yang terdapat diwebsite dikemas dalam bentuk halaman-halaman yang disebut web page,Sedangkan kumpulan dari halaman web milik suatu pihak yang disatukan disebut website $^{20}$.

\section{a. Sejarah Singkat Internet}

Sejarah internet dimulai pada tahun 1969 suatu lembaga riset Departemen Pertahanan Amerika atau Defence Advance Research Project Agency (DARPA) mendanai proyek untuk mengembangkan jaringan informasi antar beberapa computer. Awalnya lembaga ini dibuat untuk menyaingi Rusia karena pada saat itu Rusia merupakan negara unggul karena memiliki satelit. Akhirnya peneliti bekerja keras untuk melakukan penelitian diberbagai wilayah yang hasilnya akan didedikasikan untuk Amerika.

APRA memutuskan untuk membuat APRAnet untuk berkomunikasi dan mengakses data pada saat mereka tidak berada dalam satu wilayah. Sambungan atau jalur yang digunakan pada saat itu ialah kabel telephone. Akhirnya APRAnet bekerjasama dengan pihak NOVEL dengan tujuan untuk mempercepat transmisi data. Pada saat itu teknologi network hub belum ditemukan sehingga server yang ada di APRAnet harus dihubungkan satu per satu. Seiring berjalannya waktu mereka akhirnya mengembangkan

${ }^{19}$ Erima Oneto dan Yosep,Antigaptek Internet,Jakarta:PT kawan Pustaka,2009.hal.2.

${ }^{20}$ Ibid.hal.2. 
teknologi networking yang menyebabkan jumlah computer yang terhubung semakin banyak. Jaringan tersebut disebut dengan internet ${ }^{21}$.

\section{b. Metode Pembelajaran Menggunakan Internet}

Penggunaan internet kini mulai merambah kedunia pendidikan. Seiring berjalannya waktu tingkat pendidikan manusia semakin tinggi. Hal tersebut membuat kreatifitas manusia semakin bertambah. Kini banyak dijumpai situs situs pembelajaran yang dapat diakses oleh pelajar diseluruh dunia. Banyak orang-orang yang telah menempuh pendidikan tinggi membuat website yang berisi materi pembelajaran atau panduan-panduan untuk mengerjakan soal-soal. Hal ini merupakan bukti bahwa internet mampu mendukung proses pembelajaran siswa-siswi jika dapat dipergunakan sebagaimana mestinya.

Metode pembelajaran merupakan cara yang dilakukan untuk menyampaikan informasi yang berupa materi pembelajaran agar mampu dipahami oleh peserta didik dengan maksimal. Metode pembelajaran secara umum dibagi menjadi dua yakni metode tradisional dan metode online. Pada metode tradisional materi pembelajaran bersumber dari buku-buku cetak, modul, lembar kerja, artikel, jurnal, surat kabar, dan berbagai bentuk cetakan merupakan bentuk cetakan lainnya yang digunakan untuk kebutuhan pembelajaran. Bahan cetak merupakan media perantara informasi dari pengajar pada peserta didik yang mencakup sajian bahan-bahan dalam bentuk teks dan visual, publikasi, buku teks hingga jurnal ${ }^{22}$.

${ }^{21}$ Darma dkk,Buku Pintar Menguasai Internet,Jakarta:Mediakita,2009.hal.2.

22 Muhammad Yaumi,Media dan Teknologi Pembelajaran,Jakarta:PRENAMEDIA GROUP,2018.hal.208. 
Sedangkan pada metode pembelajaran yang kedua yaitu pembelajaran online. Sumber pembelajaran online merupakan berbagai materi yang dikembangkan melalui intenet yang berupa website, audio, visual, teks, multimedia atau bahkan video yang memungkinkan untuk diakses dimana saja dan kapan saja ${ }^{23}$. Situs-situs tersebut juga mampu menyediakan forum diskusi antara peserta didik dengan guru atau tutor untuk bertanya dan bertukar informasi. Hal tersebut salah satu upaya agar peserta didik menjadi lebih faham.

Setiap orang memiliki cara atau metode pembelajaran yang berbeda-beda. Seiring perkembangan zaman dan semakin derasnya arus globalisasi kini pembelajaran mulai menggunakan teknologi dan melibatkan internet. Banyak dijumpai situs-situs pembelajaran online yang mampu memberikan informasi mengenai materi pembelajaran yang dikemas menarik sesuai dengan kebutuhan peserta didik pada zaman sekarang. Kini banyak ditemui siswa-siswi yang rela mengeluarkan biaya yang besar untuk berlangganan dengan situs pembelaran online. Pembelajaran online dinilai mampu memberikan informasi yang lebih detail serta lebih akurat. Hal tersebut banyak dibuktikan bahwa siswa-siswi yang lolos seleksi masuk perguruan tinggi merupakan mereka yang rela mengeluarkan biaya untuk berlangganan situs pembelajaran online.

\section{Pengaruh Pembelajaran Online Bagi Kualitas Belajar Siswa}

\section{a. Menurut Prespektif Siswa}

Berdasarkan kuisioner online yang diberikan pada siswasiswi didapatkan hasil yang mampu menjadi indicator untuk

${ }^{23}$ Ibid.hal.208-209. 
mengukur seberapa besar pengaruh pembelajaran online terhadap kualitas belajar dan prestasi siswa-siswi. Dari tiga puluh jawaban yang diterima sebanyak $74 \%$ siswa-siswi menggunakan situs pembelajaraan online, $16 \%$ terkadang menggunakan dan $10 \%$ tidak menggunakan situs pembelajaran online.

Siswa-siswi yang menggunakan situs pembelajaran online mengatakan bahwa situs pembelajaran membantu mereka untuk lebih memahami materi juga sebagai tambahan untuk melengkapi materi yang tidak dijelaskan didalam kelas. Selain itu situs-situs tersebut mampu menambah wawasan peserta didik sehingga mereka mampu mengenal hal-hal yang baru yang tentunya membawa pengaruh yang positif yang berdampak pada penguasaan materi pembelajaran. Situs belajar online juga dinilai lebih efisien dalam memberikan informasi karena dapat diakses kapan saja dan dimana saja. Siswa-siswi yang mungkin tidak memperhatikan pelajaran ketika disekolah bisa mengaksesnya dirumah atau ditempat yang mereka sukai. Selain itu situs pembelajaran online dinilai mampu membatu mereka dalam mengerjakan variasi-variasi soal yang tidak dibahas dalam buku cetak. Situs pembelajaran memiliki sifat yang lebih fleksibel. Jika terjadi kesalahan informasi situs pembelajaran online bisa diperbaiki kapan saja. Berbeda dengan buku cetak yang jika terdapat kesalahan akan lebih fatal akibatnya. Kesalahan dalam penyampaian informasi melalui media belajar online dapat segera diperbaiki dengan proses yang lebih sederhana dibandingkan dengan buku cetak.

Situs pembelajaran online juga memiliki dampak negative bagi siswa-siswi. Menurut siswa siswi jika ditinjau dari segi keuangan, menggunakan situs pembelajaran membutuhkan biaya yang cukup mahal. Walaupun banyak juga ditemui situs yang menyediakan layanan gratis namun tetap saja membutuhkan kuota 
yang dinilai cukup mahal. Keterbatasan tersebut membuat proses tidak efektif karena akan muncul gangguan-gangguan pada saat mengakses informasi.

Dilihat dari segi kesehatan belajar menggunakan buku cetak dianggap lebih aman karena mengakses situs online dalam waktu yang lama akan menyebabkan menurunnya kesehatan mata. Cahaya yang ditimbulkan oleh layar handphone, gadget, computer atau laptop akan membawa efek pada kesehatan mata. Proses belajar setiap siswa memiliki durasi masing-masing sesuai dengan kemampuan mereka dalam memahami materi.

Kelemahan lain dari situs pembelajaran online adalah menyebabkan berkurangnya minat membaca buku. Seperti yang diketahui bersama bahwa salah satu fasilitas yang disediakan suatu lembaga pendidikan adalah perpustakaan. Perpustakaan disediakan sebagai lading untuk mencari ilmu bagi peserta didik. Dengan adanya situs-situs ini siswa-siswa akan cenderung meninggalkan buku dan beralih pada situs yang dinilai mampu memberikan informasi secara instan. Instan dalam hal ini siswa-siswi tidak harus mencari halaman demi halaman layaknya mencari informasi dibuku. Peserta didik hanya perlu mengetik materi apa yang hendak dicari pada kolom pencarian maka akan muncul informasiinformasi tersebut.

Dalam situs-situs online seringkali dimanfaatkan oleh pihak-pihak yang tidak bertanggung jawab untuk kepentingan pribadi. Banyak sekali muncul konten-konten negative baik berupa gambar, video, atau tautan. Banyak sekali gambar-gambar yang tidak seharusnya dilihat oleh kalangan pelajar. Selain itu banyak juga pihak yang mempromosikan barang-barang orang dewasa yang tidak seharusnya diketahui oleh usia pelajar. Hal tersebut akan menimbulkan rasa ingin tahu terhadap hal negative tersebut 
yang berakibat hilangnya konsentrasi belajar. Hal lain yang mampu mengganggu konsnentrasi adalah keinginan siswa-siswi untuk mengakses media social seperti facebook, twitter, instagram, path dan lain sebagainya lantaran media belajar mereka adalah gadget yang sangat memungkinkan untuk mengakses social media tersebut. Jika sudah dibuka maka tujuan awal untuk belajar akan hilang dan timbulah rasa malas.

Keresahan lain yang timbul pada saat belajar menggunakan situs pembelajaaran online adalah ketidak sesuaian materi dengan sumber-sumber ada. Dalam hal ini buku cetak dinilai lebih akurat dalam hal kebenaran informasi. Hal tersebut dikarenakan pada pembuatan buku cetak terdapat proses-proses yang cukup panjang dan editing yang cukup lama. Siswa-siswi merasa bahwa materi yang terdapat dalam situs pembelajaran online terkadang tidak sesuai dengan pemahaman mereka.

Terlepas dari kekurangan dan kelebihan tersebut siswasiswi menuliskan bahwa situs pembelajaran membawa pengaruh bagi kualitas belajar mereka. Mereka merasa bahwa diera sekarang ini informasi dapat diakses dari mana saja. Jadi pembelajaran dengan bantuan teknologi juga diperlukan agar siswa mengikuti perubahan zaman yang semakin modern seperti sekarang ini.

Bedasarkan kuisioner juga didapatkan hasil bahwa metode pembelajaran yang disukai oleh siwa antara lain dengan bertatap muka dengan guru secara langsung dengan jumlah siswa yang lebi sedikit sehingga lebih kondusif kemudian ditambah dengan menggunakan pembelajaran dengan situs online untuk mengetahui informasi yang tidak disampaikan oleh guru. Metode lain adalah dengan menerapkan problem solving dengan cara pemberian variasi soal secara bertingkat untuk meningkatkan pemahaman siswa-siswi terhadap materi yang telah diajarkan. Secara psikologi 
siswa menginginkan pembelajaran yang santai namun serius. Siswa-siswi tidak didoktrin untuk belajar terlalu keras tetapi mereka lebih senang belajar dengan diselingi dengan pemainanpermainan yang behubungan dengan materi yang dipelajari.

Dari uraian diatas maka diperlukan langkah-langkah untuk menanggulangi dampak negative serta meningkatkan dan mengembangkan lagi manfaat yang diterima oleh peserta didik. Upaya yang dapat dilakukan untuk menanggulangi dampak negative dari penggunaan situs pembelajaran online adalah dengan cara memberikan fasilitas pada siswa-siswi berupa alat-alat yang memperlancar jaringan internet sehingga mereka mampu mendapat informasi lebih cepat. Hal tersebut disebabkan siswa-siswi berasal dari kondisi ekonomi yang berbeda-beda sehingga hal tersebut berpengaruh pada pemberian fasilitas belajar mereka oleh orang tua masing-masing. Sehingga sekolah diharapkan mampu menyediakan fasilitas untuk mengatasi dampak negative tersebut.

Dampak negative selanjutnya adalah rendah nya minat membaca buku. Hal tersebut dapat diatasi dengan membagi porsi waktu kapan siswa-siswi dapat mengakses informasi melalui situs pembelajaran atau melalui internet dan waktu untuk mencari informasi pada buku teks. Memperbaiki fasilitas perpustakaan juga diperlukan untuk mengtasi dampak negative ini. Banyak ditemukan bahwa alasan siswa-siswi enggan membaca buku adalah karena suasana perpustakaan yang membosankan. Maka hal tersebut dapat diatasi dengan memberikan suasana nyaman dalam perpustakaan serta memperbanyak variasi buku-buku diperpustakaan. Bukubuku yang disediakan tidak harus buku-buku bergenre materi pendidikan tetapi juga bisa fiksi,nonfiksi, atau buku-buku yang memuat cerita inspiratif yang bisa digunakan untuk memotivasi siswa-siswi untuk menjadi lebih baik. Penyeimbangan waktu 
belajar juga perlu dilakukan. Misalnya dalam satu minggu terdapat hari tertentu dimana siswa harus membaca buku atau metode lain yang dapat membuat peserta didik terbiasa membaca buku sehingga mereka tetap memiliki waktu untuk membaca buku tetapi juga melakukan pmembelajaran dengan metode yang modern yaitu dengan mengakses situs pembelajaran online.

Cara mengatasi dampak selanjutnya yaitu ketika terdapat kesalahan-kesalahan dalam penyajian materi dalam situs pembelajaran online adalah dengan mengajak siswa-siswi untuk bersama membandingkan isi dengan referensi yang berupa buku teks. Selain itu guru harus mampu menanamkan rasa ingin tahu yang tinggi pada siswa agar tidak terbiasa terpengaruh hanya dengan satu sumber. Dengan adanya pembiasaan tersebut siswasiswi tidak akan mudah merasa puas atas materi yang didapat. Pada akhirnya siswa-siswi akan terbiasa membandingkan satu sumber dengan sumber yang lain untuk menemukan kebenaran yang mutlak. Jadi peran guru diperlukan untuk membuat mereka mampu mengendalikan rasa ingin tahu mereka untuk hal-hal yang memiliki pemgaruh positif pada penguasaan materi pembelajaran.

Permasalahan yang terjadi berikutnya adalah muncul sesuatu yang tidak layak dilihat oleh kalangan pelajar pada saat mengakses situs pembelajaran online. Pembentengan siswa-siswi dengan ilmu agama sangat diperlukan disini. Siswa-siswi yang dididik dengan dibentengi dengan ilmu agama yang baik akan dengan sendirinya mampu mengambil sikap apabila hal tersebut terjadi. Mereka akan menyadari bahwa hal tersebut tidak baik untuk dirinya dan seharusnya tidak dibuka atau ditelusuri lebih lanjut. Berbeda dengan mereka yang tidak dibentengi dengan ilmu agama yang cukup sehingga mereka akan terpancing dengan rasa ingin tahu mereka dan malah membuka hal negative tersebut. Oleh 
karena itu pembentengan ilmu agama yang cukup juga diperlukan oleh siswa-siswi selain memberikan ilmu pengetahuan mengenai hal-hal yang bersifat duniawi.

Individualis akan timbul seiring dengan perkembangan teknologi. Manusia semakin mudah melakukan segala hal sehingga tak jarang mereka lupa kodrat mereka sebagai makhluk social yang tak bisa hidup tanpa orang lain. Hal tersebut bisa terjadi dikalangan pelajar seiring berkembangnya teknologi. Kini mereka semakin mudah mengakses informasi sehingga seolah-olah mereka tidak butuh teman. Hal tersebut dapat diatasi dengan mengadakan diskusi kelompok untuk membahas suatu materi. Pembentukan kelompok-kelompok diskusi ini akan membuat siswa berinteraksi dengan siswa yang lain. Siswa-siswi akan belajar mengenai pentingnya berinteraksi antara manusia satu dengan yang lain sehingga mereka akan semakin menghargai satu sama lain. Secara tidak langsung mereka akan belajar bahwa tidak semua hal dapat mereka dapatkan melalui internet atau teknologi yang canggih tetapi juga bisa didapat dari hasil kerjasama dengan orang-orang disekitar mereka.

\section{b. Menurut Prespektif Guru}

Dalam proses belajar dibutuhkan beberapa komponen yaitu pengajar atau guru, pelajar atau murid, dan bahan ajar atau materi. Guru atau pengajar merupakan hal yang sangat penting dalam proses pembelajaran. Tanpa penjelasan guru siswa-siswi kurang maksimal dalam memahami materi walaupun tan jarang ada orang yang mampu belajar mandiri hanya dengan bantuan buku maupun internet. Berdasarkan wawancara yang dilakukan dengan guru Madrasah Aliyah Al-Bairuny didapatkan keterangan bahwa situs pembelajaran online membawa pengaruh yang baik bagikualitas 
belajar dan juga prestasi siswa-siswi. Situs pembelajaran tersebut dinilai dapat meningkatkan minat siswa-siswi untuk belajar.

Situs pembelajaran dapat membantu siswa mengakses ilmuilmu sesuai dengan yang mereka kehendaki. Dari situlah siswasiswa akan lebih mudah mengembangkan keilmuan yang mereka miliki. Situs online dapat membuat siswa-siswi dengan leluasa mengupdate informasi-informasi terbaru seputar materi-materi pembelajaran. Walaupun demikian siswa-siswi harus tetap membandingkan dengan buku-buku diperpustakaan agar tidak terpaku pada satu sumber. Siswa-siswi harus tetap berkonsultasi dengan guru untuk mendapat kebenaran yang lebih akurat.

Walaupun situs pembelajaran membawa pengaruh positif bagi kualitas belajar siswa tapi tetap saja terdapat dampak negative yang ditimbulkan dari penggunaan situs tersebut. pembelajaran dengan media internet ini member kesempatan pada siswa-siswi untuk mengakses apa saja yang tidak berhubungan dengan materi pembelajaran. Tidak jarang siswa-siswi cenderung mengakses situs-situs lain seperti media sosoal maupun game-game online.

Dari uraian diatas dapat disimpulkan bahwa metode pembelajaran dengan menggunakan situs pembelajaran online tidak selalu cocok untuk diterapkan bagi semua siswa-siswi. Bagi mereka yang memiliki kesadaran belajar tinggi maka metode tersebut dapat dijalankan. Dengan kata lain pembelajaran online dapat dterapkan pada mereka. Sedangkan untuk siswa-siswi yang masih suka bermain-main maka lebih baik dilakukan metode tradisional sehingga guru mampu mengawasi secara langsung dan mereka mampu menerima materi dengan maksimal tanpa terganggu dengan pengaruh-pengaruh lain. 


\section{Peran Pancasila dalam Mengatasi Permasalahan yang terjadi dalam Penggunaan Situs Pembelajaran Online}

Pancasila merupakan dasar negara Indonesia yang merupakan pandangan hidup bangsa. Hal tersebut berarti bahwa pancasila digunakan sebagai acuan dalam penyelenggaraan seluruh aspek kehidupan bangsa Indonesia termasuk dalam aspek pendidikan. Pancasila merupakan dasar negara yang memiliki sifat fleksibel yang mampu menyesuaikan diri dengan perubahan zaman. Seperti sekarang ini pancasila masih bisa berfungsi sebagai mana mestinya ditengah kemajuan teknologi dan derasnya arus globalisasi.

Perkembangan teknologi yang semakin maju menyebabkan adanya perubahan-perubahan disemua kalangan masyarakat Indonesia termasuk para pelajar di Indonesia. Kini seiring dengan berkembangnya teknologi dalam mengakses informasi banyak ditimbulkan permasalahanpermasalahan. Permasalahan tersebut juga timbul dalam dunia pendidikan. Dalam pembahasan kali ini permasalahan yang dibahas adalah permasalahan-permasalahan yang timbul akibat system pembelajaran yang semakin modern. System pembelajaran yang modern dapat ditandai dengan munculnya akses untuk mendapatkan informasi seputar materi pembelajaran melalui internet. Banyak dijumpai situs-situs pembelajaran yang maamou member informasi pada peserta didik yang dianggap lebih efektif dan efisien.

Namun kemajuan-kemajuan tersebut justru menimbulkan permasalahan-permasalahan. Diantaranya adalah dekadensi moral generasi muda terutama dalam hal menghargai satu sama lain layaknya kodrat manusia sebagai makhluk social. Masalah yang berikutnya adalah ketidakmerataan pendidikan di Indonesia lantaran perbedaan status social yang dapat berpengaruh pada pemenuhan fasilitas pendidikan setiap 
peserta didik. Kedua permasalahan tersebut merupakan masalah yang cukup serius. Karena menyangkut masalah kualitas generasi penerus bangsa pada masa yang akan datang.

Pancasila merupakan wujud kepribadian serta pedoman bangsa Indonesia. Oleh karena itu pancasila dipercaya mampu memberikan solusi atau menjawab segala permasalahan yang terjadi. Pancasila memiliki bunyi sebagai berikut:

1. Ketuhanan Yang Maha Esa.

2. Kemanusiaan yang adil dan beradab.

3. Persatuan Indonesia.

4. Kerakyatan yang dipimpin oleh hikmat kebijaksanaan dalam permusyawaratan perwakilan.

5. Keadilan social bagi seluruh rakyat Indonesia.

Dari kelima sila tersebut mampu menjawab permaslahanpermaslahantersebut. Permasalahan dekandensi moral atau kemunduran moral generasi bangsa serta ketidakmerataan pendidikan di Indonesia dapat diatasi dengan melaksanakan kelima sila tersebut. Pada sila pertama mengajarkan ketaatan kepada Tuhan yang jiika dilaksanakan maka manusia akan besikap sebagaimana sikap yang diajarkan oleh Tuhan mereka sehingga tidak ada lagi saling menjelekkan satu sama lain. Hal tersebut diperkuat dengan sila kedua yang memberikan pedoman bahwa manusia harus menjadi makhluk yang adil dan memiliki adab. Artinya manusia dituntut untuk melaksanakan hak dan kewajiban mereka masing masing serta bertingkah laku sesuai dengan norma yang ada sehingga moral bangsa akan selalu terjaga dan tidak terjadi dekandensi moral. Hak dan kewajiban disini merupakan hak pelajar Indonesia untuk menerima pendidikan yang semestinya yang merata. Tidak ada tindakan diskriminatif. Semua daerah memiliki hak yang sama dalam memperoleh 
fasilitas pendidikan. Dengan begitu permasalan-permaslahan pendidikan akan teratsi. Setelah dilakukannya kedua sila tersebut akan tercipta suasana damai dan semua saling menyatu satu sama lain sebagai perwujudan sila ketiga yakni persatuan Indonesia.

Pada sila keempat yakni mengangkat masalah nilai penting musyawarah. Pada permasalahan pendidikan musyawarah penting dilakukan untuk membahas apa yang harus dilakukan untuk mengatasi masalah-maslah yang terjadi. Kebebasan mengeluarkan pendapat dan pemikiran juga merupakan cara untuk mewujudkan bangsa Indonesia enjadi lebih baik. Semakin banyak aspirasi maka akan semakin banyak evaluasi yang dilakukan sehingga mampu membangun dunia pendidikan Indonesia menjadi semakin baik lagi. Setelah dilaksanakannya semua nilai maka akan tercipta keadilan bagi masyaraakat Indonesia yang dalam hal ini adalah para pelajar.

Dari uraian diatas maka dapat disimpulkan bahwa semua sila-sila mampu mengatasi semua permasalahan yang terjadi di Indonesia yang dalam hal ini adalah masalah dekandensi moral dan ketidak merataan pendidikan di Indonesia. Jadi diera milenial ini pancasila mampu menjadi acuan manusia untuk bertindak dan bersikap. Pancasila mampu menyesuaikan diri dengan kemajuan zaman sehingga selau dapat dijadikan sebagai solusi permasalahan yang terjadi walaupun zaman selalu berubah dari waktu ke waktu. Dari hal tersebut kita sebagai generasi muda seharusnya mengamalkan sila-sila pancasila agar tercipta bangsa Indonesia yang lebih baik dan lebih berkualitas.

\section{KESIMPULAN}

Dari berbagai uraian pada pembahasan yang telah disampaikan dapat ditarik kesimpulan-kesimpulan mengenai pengaruh situs pembalajaran online terhadap proses belajar siswa-siswi. Situs pembelajaran online merupakan 
metode pembelajaran yang modern yang memanfaatkan kecanggihan teknologi. Siswa-siswi mampu mengakses situs pembelajaran online dimana saja dan kapan saja. Dari penggunaan situs pembelajaran online manfaat atau kelebihan yang didapat adalah sebagai berikut:

1. Dapat diakses kapanpun dan dimanapun

2. Lebih cepat menemukan informasi yang diperlukan

3. Melengkapi materi yang disampaikan oleh guru

4. Mendukung dalam mengupdate dan menambah ilmu pengetahuan siswasiswi.

Walaupun banyak manfaat yang didapat tetapi situs pembelajaran online bisa menimbulkan dampak negative apabila tidak digunakan sebagaimana mestinya.

Berikut merupakan dampak negatif dari penggunaan situs pembelajaran online:

1. Memunculkan sikap individualis pada siswa-siswi

2. Menurunkan minat membaca buku

3. Memunculkan konten-konten yang tidak layak dilihat oleh kalangan pelajar

4. Berpengaruh pada kesehatan mata.

Jika ditinjau lebih lanjut akan timbul permasalahan dari adanya penggunaan situs pembelajaran online. Masalah yang timbul yaitu munculnya individualis dari siswa-siswi sebagai bentuk dekandensi moral dan tidak meratanya pendidikan di Indonesia karena perbedaan fasilitas pendukung kegiatan pembelajaran. Hal tersebut terjadi karena tak semua elemen siswasiswi mampu menyediakan internet dengan kualitas yang sama. Disitulah peran pancasila sebagai pedoman diperlukan. Masalah-masalah seperti 
dekadensi moral dan ketidak merataan pendidikan dapat dijawab dengan melaksanakan sila-sila pancasila.

\section{DAFTAR PUSTAKA}

Bahri, Syaiful. 1994. Prestasi Belajar Dan Kompetensi Guru. Surabaya, Usaha Nasional.

Darma, dkk, 2009, Buku Pintar Menguasai Internet, Jakarta, Mediakita.

Darmadi, 2017, Pengembangan Model dan Model Pembelajaran dalam Dinamika Belajar Siswa, Yogyakarta, Budi Utama.

Firdianti, Arinda, 2018, Implementasi Manajemen Berbasis Sekolah dalam Meningkatkan Prestasi Belajar Siswa, Yogyakarta, Grepublishing.

Husein, Hamdan, 2018, Pembelajaran Berbasis Web dengan Modle Versi 3.4, Yogyakarta, Deepublish.

Oneto,Erima dan Yosep,2009,Antigaptek Internet,Jakarta,Kawan Pustaka.

Rohaya, Siti, 2008, Internet: Pengertian, sejarah ,fasilitas dan koneksinya, Yogyakarta: diakses pada 26 Desember 2018 pukul 11.33WIB.

Rusli, Muhammad, dkk, 2017, Pembelajaran yang Inovatif Prinsip Pengembangan Model, Yogyakarta, ANDI.

Sumiharsono, Rudi, 2017, Media Pembelajaran, Jember, Pustaka Abadi.

Yaumi, Muhammad, 2018, Media Teknologi Pembelajaran, Jakarta, Prenamedia Group. 